\section{THE POLYSEMY OF “chวิJp” IN THAI: A PRAGMATICALLY MOTIVATED PHENOMENON}

\section{Kandaporn Jaroenkitboworn ${ }^{1}$}

\begin{abstract}
This paper analyzes the word chôp in Thai, which normally signifies three different meanings, namely 'to be right', 'to like' and 'often'. The result of the analysis shows that it is more likely that the polysemy of chวิدp arises from pragmatic motivation. Pragmatic motivation, which covers factors such as speakers' attitude, intention, point of view, behavior and social standing, can affect actual use of language. Pragmatically, the word chวิगp that means 'to be right' can easily lead to an action of agreement. In other words, when we regard something right; we tend to agree on it without argument. This attitude is related to another meaning of chวิsp in the way that the degree of agreeability is strengthened into the meaning 'to like', or even 'to love' and 'to enjoy' sometimes. Also, when we like something, or even love and enjoy some activity, this kind of feeling can motivate us to do it again and again and thus we come to have a characteristic behavior. This typical behavior can consequently cause semantic features like [habitual] and [iterative] to occur. With the semantic feature [iterative], the word chôp then has yet another meaning as 'often'. This paper also discusses the grammaticalization of the word chôp from a verb which
\end{abstract}

\footnotetext{
${ }^{1}$ Lecturer, the School of Liberal Arts, King Mongkut's University of Technology Thonburi, Thailand
}

means 'to like' into an adverb of frequency that means 'often' i.e. there is a change of word class or part of speech. It was found that there are many cases of chวิगp that appear syntactically and semantically ambiguous, or, in other words they are in a transitional period of word class change. This paper indicates that such an ambiguity or incipient grammaticalization is motivated by the speaker's attitude and point of view.

Key words: polysemy, pragmatic motivation, Thai, grammaticalization

\section{Introduction}

In Thai, one has often been made fun of or teased back when saying a sentence that contains the word chôp in the sense that relates to frequent events, especially those events that have a negative effect on the speaker. For example, if you say a sentence like chăn chวิगp pen wàt (which normally means 'I often catch a cold'),

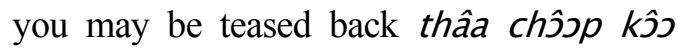
pen tว̀ paj si meaning 'if you like it, so go on catching it'.

This kind of joking can occur due to the ambiguous meaning of the word chวิวp: one meaning is 'to like', 'to love' or 'to enjoy', the other 'often' or 'frequently'. Apparently, they can be judged as homonyms i.e. two words that accidentally have the same form but with completely different meanings. Consequently, they become, needless to say, a good resource for making jokes.

In Thai, there is another chôวp which means 'to be right'. Let us consider a sentence with this chวิدp. 
(1) $\sin$ níi mâj chôpp thing this not be right dûaj kòtmăaj

by law

By law, this is not right.

Semantically, these three tokens of chวิpp seem to belong to three lexemes, which have nothing to do with one another i.e. they are homonyms. However, based on syntactic rules, many Thai dictionaries group the word chวิכp 'to be right' together with chวิכp 'to like' and separate the other chôsp 'often' due to the fact that they are different parts of speech - the first two are regarded as verbs, while the other is an adverb.

So far there has been no literature in Thai that tries to explain the relationship between these 3 (apparently separated) words chวิכp either from meaning related perspective or from the grammaticalization process. Therefore, this paper proposes to study chวิدp from not only the meaning related perspective but also its grammaticalization process. Both topics are studied in this paper with the focus on polysemy with pragmatic motivation.

\section{Homonymy and Polysemy}

Before analyzing the case of chวิدp in Thai from a pragmatic perspective, let us consider some basic concepts in semantics first as good grounding for the following study of chôpp in depth. Semantically, Lyons (1995: 58) explained the difference between homonymy and polysemy in that the former is a relation that holds between two or more distinct lexemes, whereas the latter is a property of single lexemes i.e. one lexeme with multiple meanings. He also proposed criteria to separate homonymy from polysemy which can be summarized as follows:

1. homonyms are unrelated in meaning

2. all their forms are identical

3. their identical forms are grammatically equivalent.

According to Lyons (1995: 55), the three criteria above are used to judge what he called "absolute homonymy." Absolute homonyms refer to two or more lexemes that have the same phonological and orthographic form, grammatical equivalence (for example, they belong to the same part of speech), but have no relation in meaning. ${ }^{2}$ The word "bank" in English is a good example: one means a financial institution, whereas the other refers to the sloping side of a river. Clearly, the two meanings have nothing in relation to one another, so they pass the first criterion. Also, they pass the second criterion as they share the same form $<$ bank $>$. Moreover, they both grammatically belong to the same word class, that is, noun class.

In the case of chวิدp in Thai, on the other hand, it is hard to say that the first criterion is adequately a clear-cut tool to separate them into 3 lexemes. At first glance, the chวิכp meaning 'to like' and the chวิכp meaning 'often' can be said to be unrelated in meaning. Therefore, they appear to pass the first criterion: homonyms are unrelated in meaning. Besides, they share the same form, so they pass the second criterion. Syntactically,

\footnotetext{
${ }^{2}$ On the other hand, partial homonyms, according to Lyons (1995: 55), may satisfy one or two of the criteria, but not all the three. In this article, however, only the absolute homonymy is the focus and is referred to as just "homonymy" in short.
} 
however, they form different parts of speech. To prove this, one can put the negative marker mâj before the former in order to produce the opposite meaning ('not like'), but one cannot do the same to the latter (to get the negative meaning "not often'). ${ }^{3}$ Therefore they do not pass the third criterion and thus it can be concluded that they are not homonyms.

Let us go back to consider the first criterion which concerns the words' different meanings. Based on this criterion, as I have mentioned earlier, it seems that the meanings of the two chôp's have nothing to do with each other: one concerns emotion whereas the other concerns the frequency of time. Nevertheless, the verb chวิدp which means 'to like' can sometimes co-occur with other verbs in a form of socalled "serial verbs" and this causes chว̂p to have a meaning of 'to love' or 'to enjoy (doing something)." Let us consider an example:

\section{(2) chăn chôsp kin chókkoolæt I like eat chocolate I like eating chocolate.}

\section{(3) chăn chว̂วp lên intəanèt I like play Internet I like surfing the Internet.}

Pragmatically, what we like to do or enjoy can motivate us to repeat doing it very often and consequently it becomes our habit or characteristic behavior. As a result, considered from a semantic point of

\footnotetext{
${ }^{3}$ Instead, if one puts the negative marker before the adverb 'often', the word's meaning will be changed into 'to like' or 'not like' immediately. Grammatically, adverbs and other parts of speech in Thai cannot be negated. Only verbs can.
}

view, the meaning of enjoyment can metonymically covers features like enjoyable, habitual and iterative. According to De Smet and Cuyckens (2005), the sense of habituality involves iterativity due to the fact of a situation's repeated occurrence. Therefore, the chวิכp which is an adverb that means 'often' is semantically related to the chôวp 'to like' by the feature iterative. Both of them are in fact polysemous words, not homonyms at all.

The other chวิدp 'to be right' happens to share the same form with the chôp 'to like' and belongs to the same part of speech, i.e. verb, and therefore it passes both the second and third criteria. For the first criterion, however, I will argue that it does not pass, since it has a relation in meaning with the chวิכp 'to like' and should be considered as a polysemous word. I will discuss this point in more depth later.

\section{Polysemy as Semantic Extension}

Lyons (1995: 58) mentioned earlier that polysemy was a phenomenon in which one lexeme had multiple meaning. By multiple meaning, numerous literatures in cognitive semantics describe polysemy as meaning extension, or more specifically speaking, metonymical and metaphorical extension (e.g. Talmy 1985, Taylor 1989, Lakoff 1987, 1990, Kövecses 2002). A good example in English is the word "see": one refers to "to have visual experience", while the other "to understand." Metaphorically, the former belongs to physical space as one needs eyes to perform such an action, whereas the latter extends to mental space.

The study of three visual perception verbs in Thai by Rungthip Rattanaphanusorn (2006) corroborates this cognitive theory 
of polysemy. The researcher found that the 3 verbs, which are moכ 'to look', duu 'to watch' and hěn 'to see', share the basic sense of direct visual perception in a physical domain and then extend to the mental domain. For example, hěn 'to see' extends metaphorically from 'to perceive with eyes' to 'to know' and 'to believe.'

Let us get back to consider the word chวิدp in Thai through the following sentence:

\section{(4) khârâatchakaan khon níi civil servant person this pràphrit mí chôวp behave not right This civil servant does not behave right.}

The word chวิدp in (4), which means 'to be right', can be said to belong to both physical and mental spaces as it is still concerned with a description of human behavior as well as making judgment on one's behavior based on law and social value. Another chôsp 'to like', on the other hand, probably extends from the former towards mental space as it only concerns emotion. The other chวิدp 'often' finally extends into a time dimension.

Even though we can describe the path of its extension from the physical dimension to the very abstract one with a cognitivesemantic approach, the description is nonetheless inadequate to explain what motivates this path.

\section{Polysemy and Pragmatic Motivation}

In the previous section, I have clearly shown that the two senses of chôsp 'to like' and 'often' are semantically related by pragmatic motivation. In other words, if we do not take the real use in context of this word as well as the related behavior and the attitude of the speaker into account, this phenomenon cannot be explained clearly from a broader perspective. It is likely that pragmatics motivate the emergence of semantic features. Therefore it can be said that polysemy is a pragmatically motivated phenomenon i.e. pragmatics come first, and only then do semantic features or new related meanings arise.

The 20th-century philosopher Ludwig Wittgenstein (1978) contends that meaning is related to usage. Hence, words are neither defined by reference to the objects or things which they are designated by the world nor by the thoughts, ideas, or mental representations that one might associate with them, but rather by how they are used. In his view, meanings emerge from what he termed "forms of life", roughly speaking, the culture and society in which those words are used.

John Langshaw Austin occupies a place in the philosophy of language alongside Wittgenstein in staunchly advocating an examination of the way words are used in order to elucidate meaning. His famous work "How to Do Things with Words" (1962) gives priority to illocutionary acts to analyze meaning. His speech act theory has since become world famous. And this has partly lead to a new perspective of meaning: the "speaker's meaning" which includes aspects such as the speaker's intention, point of view, attitude and the 
way or manner by which the speaker delivers his/her words.

Following Wittgenstein and Austin who give priority to the way we use a language, the way the speakers live their lives, and how the speakers think or feel, we can explain the chว̂วp which means 'to be right' and consider that it is also related to the chôวp which means 'to like' as well. Pragmatically, if we consider something or someone to be right, we tend to agree on it or agree with him or her without any argument. Based on Austin's key notions of locutionary and illocutionary acts, or what is said and what is communicated or how it is communicated respectively, it can be said that when Thai people use the word chวิدp 'to be right', they are simultaneously performing the act of agreement as well as communicating a positive attitude. In other words, they are not just saying something but also doing something as well. As the act of agreement with a positive attitude has been repeated along with the frequent use of chว̂p 'to be right', the degree of agreeability with positive feelings is then strengthened and this possibly motivates another meaning 'to like' to emerge. Along with the way Thais use chôpp 'to be right', which is associated with social values and laws (in order to make a judgment), it is likely that these social values and laws have the power to possibly direct or influence one's opinion and emotion (either consciously or unconsciously). This is possible since the speaker's meaning is context sensitive.

There is further evidence that can help support the idea that chวิJp 'to be right' has motivated us to perform an act of agreement. The best evidence that I am going to talk about is the compound hěnchวิวp. Literally, this verb compound is composed of two verbs hěn 'to see' and chวิPp 'to be right'. The outcome of their combination is the meaning 'to agree'.

Even though this paper is limited to synchronic study, it is likely that the word

chวิכp 'to be right' had emerged first, then lead to the emergence of the compound hěnchวิPp and the verb chวิدp 'to like' respectively. This assumption can be partly proved by the use of chวิכp 'to be right' at the present where it occurs only in a formal style of language use such as in law and in teaching words by the Lord Buddha. My observation conforms to other research by Thompson and Mulac (1991) and Moore (2007) which show that polysemy and grammaticalization are associated with frequency and register. That is, when a word's meaning is being extended and grammaticalized, the original one tends to be restricted in everyday use as well as in certain registers.

Let us take the assumption that the chôpp 'to be right' had emerged first as a starting point; the chวิدp 'to be right' can be then semantically linked to the chôsp 'to like' as polysemous words. As mentioned earlier, it is possible then that the degree of agreeability is consequently strengthened to 'to like', 'to love' and also 'to enjoy'. Pragmatically, when we agree on something, either someone else's idea or action, we tend to have a positive attitude or good feeling toward it. The positive attitude and good feeling can motivate us to have the emotion of (or the meaning) 'to like'. After that, the degree of 'to like' is possibly strengthened into 'to love' and 'to enjoy'. 


\section{Grammaticalization and Pragmatic Motivation}

Grammaticalization is a phenomenon in which a word comes to be more than one part of speech or have more grammatical functions. Also, its meaning is changed while being grammaticalized. On the whole, a content word tends to change into a function word (Hopper and Traugott 1993). Numerous researchers such as Traugott (1982) and Rossari, Ricci and Spiridon (2009) contend that grammaticalization is not a phenomenon of syntactic and semantic change alone but also a pragmatically motivated phenomenon.

As already mentioned earlier that one chôวp is a verb meaning 'to like' and the other is an adverb meaning 'often', in this section their grammaticalization process will be examined. Based on the syntactic environment, they have already been analyzed to show that they belong to different word classes; it can be proved by the negation process. In this way, semantic bleaching also helps explain their grammaticalization process. The semantic feature enjoyable is bleaching while the feature iterative is being highlighted. Speaking from a pragmatic viewpoint, the feature iterative has emerged due to the fact that whatever one likes to do is normally repeatedly done. Therefore the chวิدp 'to like' is grammaticalized into an adverb which means 'often'.

However, when the grammaticalization is in progress or getting started, there are normally some ambiguous cases i.e. one form is possible to be interpreted as belonging to two word classes or to have two possible meanings. Let us consider an example:

\section{(5) İ̀n chôsp lěntua}

she like/often play hard to get She likes playing hard to get./ She often plays hard to get.

From the point of view of the speaker, who is a man (according to the corpus of the Thai Online Concordance Program provided by Chulalongkorn University), it seems that chôsp in (5) means 'often'. In other words, this utterance may imply that she often performs the action (of playing hard to get) which I dislike. However, from the viewpoint of the woman who is being referred to, it might be possible that she enjoys doing such a thing.

\section{(6) Nákkaanmuean sùanjàj politician most chวิכp kગכrápchân like/often be corrupt Most politicians like to commit corruption/ most politicians often commit corruption.}

Likewise, chวิدp in (6) is ambiguous. If we interpret this from the point of view of common people who feel like they are being taken advantage of, chวิכp should be the adverb 'often'. It implies that what most politicians have done is too much to bear. On the contrary, it is possible to say from the point of view of the politicians that they love to do it. Furthermore, sentence (6) can be interpreted as stating the fact that most politicians enjoy being corrupt and indeed frequently doing so. Therefore, it is the context which is important e.g. who the speaker is, the purpose of uttering this sentence (just to report a fact or to complain about something) etc.

Based on data from the Thai Concordance Program (Chulalongkorn University), the 
cases that are not ambiguous or where chวิدp is surely the adverb, is when chôวp cooccurs with a verb or phrase that implies a negative sense or concerns a situation with negative effects as in (7).

(7) phǒm chวิدp pùathǔa I often have a headache toכn cháw in morning I often have a headache in the morning.

The verb pùathǔa 'have a headache', when standing alone in the dictionary, does not have a negative or positive sense; it just describes a symptom. However, when it is used in context, it turns into having a very clear negative sense, since nobody wants to undergo such a painful event. Therefore it cannot be said that chวิכp in (7) has the meaning 'like' at all. Syntactically, we cannot put the negative marker ' $m a \hat{j}$ ' before this chวิدp to get the opposite meaning 'not often'.

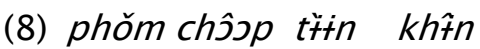
I often wake up klaan dłk phró fănráaj mid night because nightmare I often wake up at night because of nightmares.

Like (6), ť̈tn kht̂n 'wake up' when standing alone does not imply any negative sense at all. However, the context or co-text phró fănráaj 'because of nightmares' helps support the chôวp to be interpreted as an adverb 'often' (instead of 'to like'), since nobody likes to experience a situation as in (8). Or putting it another way, everyone wants to sleep well throughout the night.
As can be clearly seen, the attitude and viewpoint of the speaker plus the context of language usage are probably the main factors that motivate chôsp to be grammaticalized.

\section{Conclusion}

This paper analyzes the word chôวp in Thai, which is normally used to signify three (apparently) different meanings, namely 'to be right', 'to like' and 'often'. These three apparent separate words are actually polysemous words and it can be said they are originally related due to pragmatic motivation. This analysis is just a case study to show that semantics alone cannot explain polysemy well enough, but a study of pragmatics does. In addition, this paper studies the grammaticalization of the word chวิدp, which is also concerned with polysemy. The results show that incipient grammaticalization of chวิวp is pragmatically motivated as well. In conclusion, it can be said that originally, polysemy, either as one topic studied within semantics or in a grammaticalization concerned phenomenon, is pragmatically motivated.

\section{References}

Austin, J.L. 1962. How to do Things with Words. Oxford: Clarendon Press.

Smet, De and Cuyckens. 2005. Pragmatic Strengthening and the Meaning of Complement Construction. Journal of English Linguistics 33.1: 3-34.

Hopper, P.J. and Traugott, E.C. 1993. Grammaticalization. Cambridge: CambridgeUniversity Press.

Kövecses, Z. 2002. Metaphor: A Practical 
Introduction. New York: Oxford University Press.

Lakoff, G. 1987. Women, Fire and Dangerous Things. Chicago: University of Chicago Press.

---. 1990. The Invariance Hypothesis: Is Abstract Reason Based on Image Schema? Cognitive Linguistics 12.1: 39-74.

Lyons, John. 1995. Linguistic Semantics. Cambridge University Press: Cambridge.

Moore, Colette. 2007. The Spread of Grammaticalized Forms: The Case of be+supposed to. Journal of English Linguistics 35.2: 117-131.

Rattanaphanusorn, Rungthip. 2006. Semantic Extension of Visual

Perception Verbs (การขยายความหมายของ คำกริยาแสดงการรับรู้ด้วยตาในภาษาไทย). Dissertation. Chulalongkorn University. (in Thai)

Rossari, C., Ricci, C., and Spiridon, A. (eds). 2009. Grammaticalization and Pragmatics: Facts, Approaches, Theoretical Issues. Bingley: Emerald Group Publishing Ltd.

Talmy, L. 1985. Lexicalization Patterns: Semantic Structure in Lexical Form. Language Typology and Syntactic Description, edited by T. Shopen, pp. 57-149. Cambridge: Cambridge University Press.

Taylor, J. R.1989. Linguistic Categorization: Prototypes in Linguistic Theory. Oxford: Clarendon Press.
Thompson, Sandra A., and Anthony Mulac. 1991. A Quantitative Perspective on the Grammaticalization of Epistemic Parentheticals in English. Approaches to Grammaticalization vol.2, edited by Traugott and Heine, pp. 313-329. Amsterdam: John Benjamins.

Traugott, E.C. 1982. From Propositional to Textual and Expressive Meanings: Some Semantic-Pragmatic Aspects of Grammaticalization. Perspectives on Historical Linguistics, edited by W.P. Lehman and Y. Malkiel, pp. 245-271. Amsterdam: John Benjamin.

Wittgenstein, Ludwig.1978. Philosophical Investigations. Translated by G.E.M. Anscombe. Oxford: Basil Blackwell. 